\title{
EARLY SPRING FLOWERS
}

Photographed by Fenton Vance, Regina

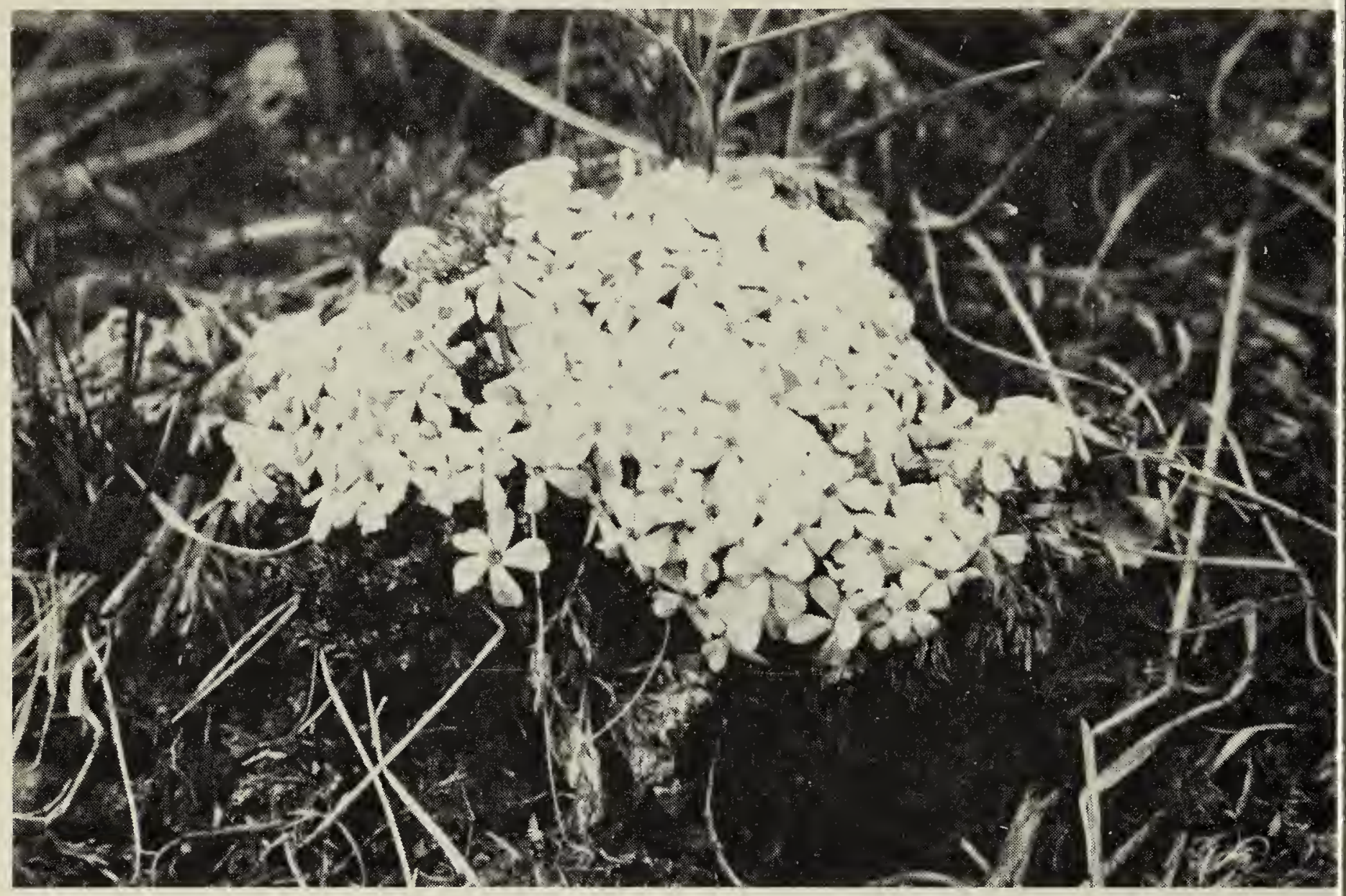

Moss Phlox

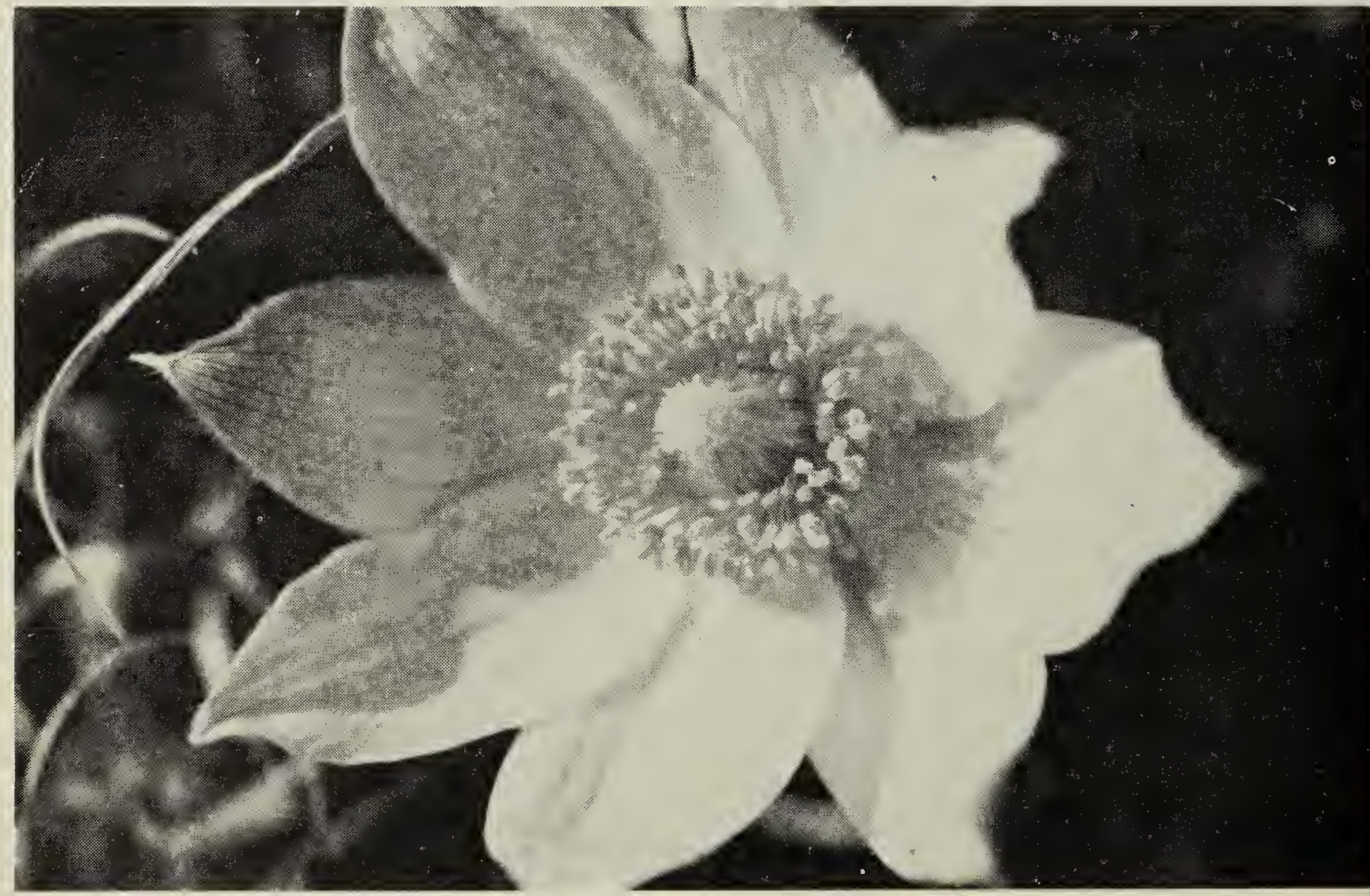

Crocus Anemone 